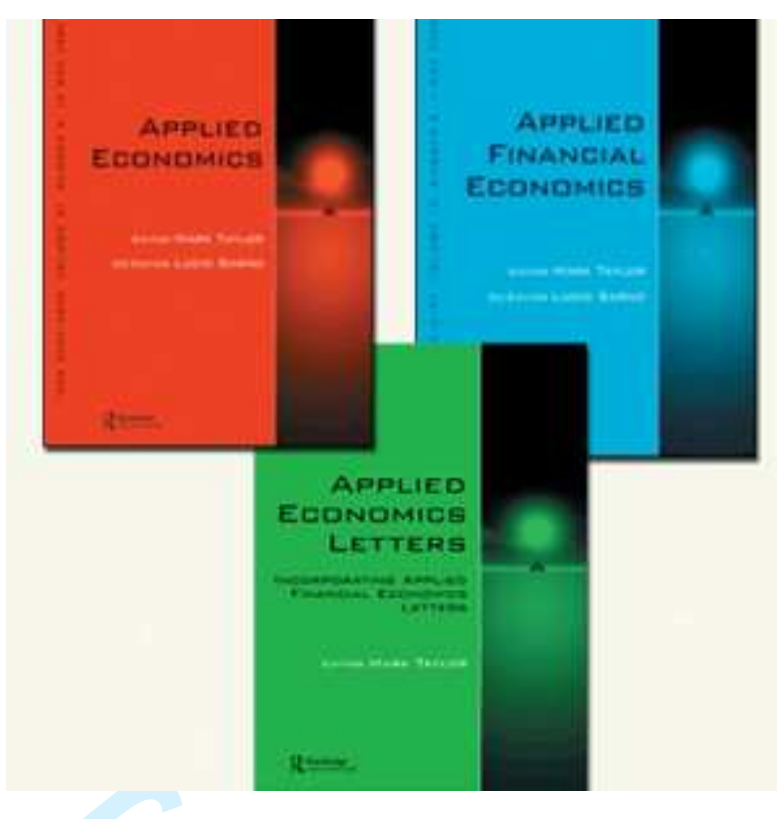

\title{
Self-employed Mothers and the Work-Family Conflict
}

\begin{tabular}{|c|c|}
\hline Journal: & Applied Economics \\
\hline Manuscript ID: & APE-2010-0421.R1 \\
\hline Journal Selection: & Applied Economics \\
\hline $\begin{array}{r}\text { Date Submitted by the } \\
\text { Author: }\end{array}$ & 21-Jan-2011 \\
\hline Complete List of Authors: & $\begin{array}{l}\text { Molina, Jose Alberto; University of Zaragoza; Institute for the Study } \\
\text { of Labor-IZA } \\
\text { Gimenez-Nadal, Jose; University of Zaragoza; Centre for Time Use } \\
\text { Research, University of Oxford } \\
\text { Ortega, Raquel; University of Zaragoza }\end{array}$ \\
\hline JEL Code: & $\begin{array}{l}\text { C14 - Semiparametric and Nonparametric Methods < C1 - } \\
\text { Econometric and Statistical Methods: General < C - Mathematical } \\
\text { and Quantitative Methods, D13 - Household Production and } \\
\text { Intrahousehold Allocation < D1 - Household Behavior and Family } \\
\text { Economics < D - Microeconomics, J12 - Marriage|Marital } \\
\text { Dissolution|Family Structure < J1 - Demographic Economics < J - } \\
\text { Labor and Demographic Economics, J13 - Fertility|Family } \\
\text { Planning|Child Care|Children|Youth < J1 - Demographic Economics } \\
<\mathrm{J}-\text { Labor and Demographic Economics, J22 - Time Allocation and } \\
\text { Labor Supply < J2 - Time Allocation, Work Behavior, and } \\
\text { Employment Determination/Creation < J - Labor and Demographic } \\
\text { Economics }\end{array}$ \\
\hline Keywords: & Self-employment, Market Work, Child care, Timing \\
\hline
\end{tabular}




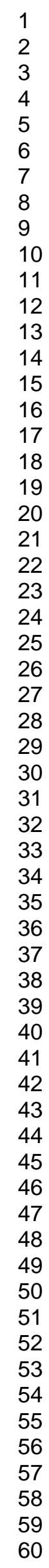

SCHOLARONE ${ }^{\text {M }}$
Manuscripts

10

12

13

14

15

16

18

19

20

22

23

25

26

27

29

32

33

34

35

36

39

40

41

43

44

45

46

47

48

50

51

52

54

55

57

58

60

Editorial Office, Dept of Economics, Warwick University, Coventry CV4 7AL, UK 


\title{
Self-employed Mothers and the Work-Family Conflict
}

\author{
Jose Ignacio Gimenez-Nadal $^{1,2} \quad$ Jose Alberto Molina ${ }^{1,3} \quad$ Raquel Ortega $^{1}$ \\ ${ }^{1}$ University of Zaragoza (Spain) \\ ${ }^{2}$ Centre for Time Use Research, University of Oxford (UK) \\ ${ }^{3}$ Institute for the Study of Labor-IZA (Germany)
}

\begin{abstract}
We analyze how self-employed and employed mothers allocate their time throughout the day in order to balance their work and family responsibilities. To that end, we use time diary information from Spain, a country with a low level of women's participation in the labor market (Spanish Time Use Survey, 2002-2003). We find that self-employed mothers devote less time to market work, and more time to tertiary (e.g., sleeping, eating) and leisure activities, than employed mothers in a working day. We also find differences between employed and self-employed mothers in the timing of market work, child care and housework throughout the day, and we find complementarities between the timingof market work of working mothers and the timing of child care of their male partners. Our results on timing are consistent with the hypothesis that self-employment stands as a possible way for mothers to have greater control over the timing of work (flexible hours), and that they may therefore be able to work odd shifts, when the spouse is available to care for the children.
\end{abstract}

JEL: C14, D13, J12, J13, J22

Keywords: Self-employment, Market Work, Child Care, Timing.

We are grateful for comments from the European Society for Population Economics Conference (2008), the Spanish Applied Economics Meeting (2008), the European Economic Association Conference (2008) and from the Annual Conference of the European Association of Labour Economics (2008), as well as the financial support provided by the Spanish Ministry of Education and Science (Project ECO2008-01297), and the Ramon Areces Foundation.

Correspondence: J. Ignacio Gimenez-Nadal, Department of Economic Analysis, Faculty of Economics, Gran Via 2. 50005 - Zaragoza (Spain). Tel.: +34 976761000 ext. 4653 Fax: +34 9767619 96. E-mail: ngimenez@unizar.es 


\section{Introduction}

Recent decades have brought about a noticeable change in the role of women in the labor market. The female labor force participation rate in the United States, as in Northern European countries, is approximately $70 \%$, significantly higher than in Southern European countries, such as Spain, which has a participation rate of around $58 \%$ (OECD, 2005). These figures point to changes in social and gender roles (Layard, 2005) and indicate that roles taken by married/cohabiting women have changed during recent decades, with many such women having now become paid workers as well as homemakers.

However, most women continue to do more of the housework and parenting (Robinson and Godbey, 1997; Bianchi et al., 2000; Coltrane, 2000; Aliaga, 2006), with this creating an extra strain, the so-called "double burden" or "second shift" (Hochschild and Machung, 1989; Schor, 1991; Hochschild, 1997). ${ }^{1}$ Thus, women show discontent with the amount of free time available to them (Robinson and Godbey, 1997; Bittman and Wajcman, 2000; Mattingly and Bianchi, 2003; Sayer, 2005; Mattingly and Sayer, 2006), and the increased popularity of workplace flexibility programs and supportive workfamily policies reflects the intensification of the conflict between working and household responsibilities usually associated with negative consequences for workers' health and workplace performance (Netemeyer et al., 1996; Kossek and Ozeki, 1999; Allen et al., 2000; Grzywacz and Bass, 2003; Byron, 2005; Mesmer-Margnus and Viswesvaran, 2005a, 2005b).

Given these realities, one commonly-held view of women's motives to choose self-employment is a desire for greater flexibility, and the ability to spend more time caring for children (Presser, 1989; Connelly, 1992; Loscocoo, 1997; Caputo and Dolinsky, 1998; Boden, 1999; Hundley, 2000; Lombard, 2007; Arai, 2008). Within this framework, the objective of this paper is to analyze whether self-employment stands as a possible way for mothers to have greater control over the hours they work (flexible hours) and we examine how self-employed and employed mothers deal with conflicting family and work pressures.

\footnotetext{
1 For instance, by the end of the 1990's, men in some OECD countries devoted 3.29 hours per day to household production activities (housework plus child care), whereas women devoted 6.04 hours per day to such activities (Gauthier et al., 2004). Poortman and van der Lippe (2009) show that women have more favorable attitudes toward cleaning, cooking and child care than do men, a finding associated with women's greater contribution to household labor.
} 
To that end, we use data from Spain, where labor markets remain highly regulated, with strict rules concerning the hiring and firing of workers, and the types of employment arrangements permitted. This contributes to the emergence of obstacles to leaving and re-entering the labor market, while becoming a parent and raising children, and results in women in Spain participating less in the labor market and having fewer children (Del Boca, 2002). Furthermore, child care services in Spain are typically inadequate and characterized by extreme rigidity in the number of weekly hours available. Only $2 \%$ of child care slots for children up to age 3 are publicly funded, which is the lowest percentage in Europe. Parental leave in Spain is granted to families rather than to individuals, for a maximum of 36 weeks, unpaid, and offers no flexibility at work. ${ }^{2}$

We contribute to the existing US literature on the relationship between selfemployment and the work-family conflict by providing evidence for a European country, Spain, representing the Mediterranean rim. Although North American studies focusing on self-employment have indicated that self-employed women find it easier to combine work and family responsibilities than employed women (Goffee and Scase, 1983; Scott, 1986; Kaplan, 1988; Buttner, 1993; DeMartino and Barbato, 2003; Lombard, 2007), little actual empirical work has been carried out in this area in the European context. Likewise, given previous evidence hypothesizing that self-employed mothers spend less time in the labor market and more time caring for their children than do employed mothers, we analyze whether self-employed mothers devote more time to child care activities than employed mothers. We also analyze whether the timing of activities for self-employed mothers differs from that of employed mothers, allowing self-employed mothers to shift part of their working responsibilities to unusual hours, and to devote more time to child care activities during the mornings.

We find that self-employed mothers devote less time to market work and more time to tertiary activities (e.g., sleeping, eating) and leisure activities than employed mothers in a working day. This evidence is in line with Reynolds (2005) who finds that 'work-life conflict makes women want to decrease the number of hours they work whether the conflict originates at home or at work.' Given the desire to reduce the amount of work hours for mothers who are dealing with conflicting family and work pressures, selfemployment allows for such reduction.

\footnotetext{
2 The Spanish institutional context has improved somewhat in recent years, with the implementation of certain familyfriendly policies and, although the portion of GDP devoted by the government to gender equality policies has increased from $0.5 \%$ in 1998 to $1.1 \%$ in 2005, this is still the lowest in the European Union (EUROSTAT). Such policies include the "baby-check" (€2,500), and the Spanish law "Ley para la igualdad efectiva de hombres y mujeres 2007/3".
} 


\section{Data and Variables}

We use the Spanish Time Use Survey-STUS (2002-2003), where each household member over 9 years old fills in a time sheet, covering the 24 hours of a day, from 6 a.m. to 6 a.m. the following day. This dataset allows us to accurately compute the total effective hours devoted to different activities, and to analyze the timing of these activities to identify changes in the underlying 'time-profiles' throughout the day (for studies analyzing the timing of activities, see Hamermesh $(1998,1999)$ and Fisher et al. (2007) for the US; Bonke et al. (2004) for Denmark; Hyytinen and Ruskanen (2007) for Finland).

The sample is restricted to include employed and self-employed working mothers of children under 18, living in heterosexual couples (married or cohabiting), with no other restrictions concerning the presence of other family member, health status, or rural/ urban status. ${ }^{3}$ Additionally, we look at working days, defined as days where people devote at least 60 minutes to market work activities, excluding commuting. The time constraint is more likely to become binding during a working day, when people must devote time to their work responsibilities, and, hence, the work-family conflict is more likely on such days.

\footnotetext{
${ }^{3}$ Despite the inherent diversity of the term "self-employed", we use the generally accepted meaning, which refers to those individuals who are either entrepreneurs with no employees, or independent workers, since our data set does not allow us to distinguish between these two categories. Self-employed women can also define themselves as working parttime.
} 


\section{Dependent variables}

Since there are a large number of different activities, we need to devise some way to aggregate these activities into useful economic categories, and thus we have chosen the 4 main categories used by Burda et al. (2008): Market Work, Household Production, Tertiary Activities and Leisure.

Market Work refers to activities for which people are paid. Household Production refers to activities in which we engage at home, using our own time and some purchased goods, and have the common characteristic that we could pay someone to perform them for us, while we are not paid for performing them. The third group is Tertiary Activities, which refers to things that we cannot pay other people to do for us, but that we must do for ourselves, at least to some extent (e.g., sleeping, eating). Finally, Leisure includes all activities that we cannot pay someone else to do for us, and that we do not really have to do at all if we do not wish to. What distinguishes Leisure from other types of home activities is that one can function perfectly well, albeit not necessarily happily, with no leisure whatsoever. In other words, Leisure is not necessary for survival. ${ }^{4}$

Regarding these activities, while employed mothers may consider time spent with coworkers, colleagues, and clients, other than while working, as Leisure, self-employed mothers may consider such time as part of the job, since the success of their economic activities or business depends on their ability to win clients (networking). This may result in the self-employed considering some activities as Market Work, while the employed consider the same activities as Leisure. Thus, the potential difference in the time devoted to Market Work by both groups may be upwardly biased. We also find a downward bias in commuting time. Travel to/from work may make a difference in the time devoted to Market Work between employee and self-employed mothers, since the self-employed can be working at home and, therefore, we do not include commuting time in Market Work.

Additionally, Child Care poses a conceptual challenge (Aguiar and Hurst, 2007). It has been argued that Child Care differs from Housework in terms of the utility generated. For example, when asked to assess the satisfaction they receive from various activities, individuals consistently rank time spent playing with and reading to their children as being among the most enjoyable (Robinson and Godbey, 1997). Furthermore, individuals consistently report that general Child Care is more enjoyable than activities such as

\footnotetext{
4 All these activities are measured as primary activities. Väisänen (2006) shows that the amount of time reported as secondary activity in the STUS is 82 minutes (out of 1440 minutes per day), the lowest among the UK, Finland, France, Germany, Italy, Norway and Sweden, which makes the inclusion of secondary activities in the analysis not relevant.
} 
housework, grocery shopping, yard work, cleaning, doing dishes and laundry. Such survey evidence suggests that it may be appropriate to examine Child Care separately from other categories of time use, such as leisure and housework.

\section{Explanatory variables}

We control for age and age squared divided by 100 (Kalenkoski et al., 2005; Aguiar and Hurst, 2007), in order to account for the allocation of time over the life-cycle. For instance, we should expect an inverted U-shaped effect of age on Child Care activities, since the majority of Spanish women have children when in their early 30s, and the time required for Child Care decreases as children grow older. ${ }^{5}$ We also consider the effects of family structure (Kalenkoski et al., 2005), controlling for the number of children in the household, breaking down children's age according to school cycles (Number of children 0 2, Number of children 3-5, Number of children 6-12, Number of children 13-17). We also control for the number of members in the family, since it is possible that the presence of grandparents (especially grandmothers) reduces the time devoted to Household Production and Child Care activities.

We control for whether mothers live in an urban or rural area (Kalenkoski et al., 2005). The availability of child care services, which may be more limited in rural areas, may condition the time allocation of mothers, and they may find more difficulty combining work and family responsibilities, making self-employment a viable way to alleviate this conflict. Additionally, Kalenkoski et al. (2005) find that, if women have any health limitations, they devote less time to Market Work. For this reason, we control for the self-reported health status of the mothers $(5=$ very poor, $\ldots, 1=$ very good).

We also control for the educational level of the mothers (Kalenkoski et al., 2005; Aguiar and Hurst, 2007). Aguiar and Hurst (2007) show a dispersion of Leisure favoring the less-educated, while Kalenkoski et al. (2005) find that highly-educated women devote more time to Market Work and Child Care. We use two dummy variables to control for university and secondary levels of education (the reference category is primary education). We also control for marital status (Kalenkoski et al., 2005), with the reference category being cohabiting (vs. married).

\footnotetext{
${ }^{5}$ According to EUROSTAT, the mean age of women at first birth in 2002 was 30.77 years in Spain.
} 
Additionally, we need to control for the work characteristics of the mother. Hence, we control for part-time (self-reported) and self-employment (self-reported) status, occupation, and own hourly wage. First, we acknowledge that the part-time and self-employment status are choice variables (e.g., Lombard (2007) finds that a woman is more likely to choose self-employment the greater her demand for flexibility), although we consider them to be exogenous variables, since we are interested in whether these choices affect the mothers' allocation of time. Second, we need to control for the occupation of the individual (type of work), since it could be that the number of hours devoted to Market Work, and the timing of these activities, is in fact a function of the type of work, rather than of an individual choice. ${ }^{6}$ Third, according to Altman (2001), whether labor supply increases or decreases, as a consequence of a change in real wages, depends on whether or not the substitution effect outweighs the income effect. But such a link is analytically suspect, since we do not know, a priori, the reasonable circumstances under which one effect should outweigh the other, nor the circumstances under which the elasticities of price and income effects can be expected to be large or small.

Thus, we use two dummies to control for the part-time $(1=y e s ; 0=$ no $)$ and selfemployment status $(1=$ yes; $0=$ no). For occupation, we have considered the 11 categories used in Hersh (2009). ${ }^{7}$ Finally, we include the (log) hourly wage rate to control for income and substitution effects. To compute the own wage rate, since income in the STUS is defined in intervals, we first assume an underlying normal distribution of the earnings variable, and apply interval regression techniques to compute the expected value (mean) of earnings in each of the earnings intervals. Once we obtain the expected value of earnings, we divide such earnings by the hours per week devoted to market work activities. To allow for non-linear effects, we use the logarithm of wage rate. ${ }^{8}$

\footnotetext{
${ }^{6}$ For instance, if the self-employed mother is opening a new restaurant, she would be less likely to be flexible than a regular employee. Furthermore, the type of commitment required by so-called 'high-powered' jobs, such as law or medicine, may require a significant amount of up-front time in order to become established, so being self-employed may also predict working longer hours, less time spent with children, and less flexibility. Thus, a comparison between the self-employed and the employed, without controlling for the type of job, may be misleading.

7 We control for the following occupations: Management, business, financial; Professional and related; Healthcare support; Protective service; Food Preparation and serving related; Building and grounds cleaning and maintenance; Personal care and service; Sales and related; Office and administrative support; Natural resources, construction and maintenance; and Production, transportation and material moving.

8 The same imputation technique is used in Sevilla-Sanz et al. (2010.
} 


\section{Descriptive evidence}

Panel A in Table 1 shows means and standard deviations of the time use variables for employed and self-employed mothers of children under 18 in a working day. Although we find differences in the time devoted to their daily activities between employed and self-employed mothers, most such differences are not statistically significant at the $5 \%$ level. We only find a statistically significant difference between employed and self-employed mothers in the amount of time devoted to Tertiary Activities, since self-employed mothers devote 16.93 more minutes per working day to Tertiary Activities, compared to employed mothers. This result is consistent with Hyytinen and Ruskanen (2007) who find that Finnish self-employed individuals get more sleep.

Panel B in Table 1 shows summary statistics of the explanatory variables in our sample. We find no statistically significant differences at the 5\% level among employed and self-employed mothers in age, number of family members, health status, civic status and number of children. However, we do find statistically significant differences at the $5 \%$ level for other demographic characteristics. Spanish self-employed mothers are less likely to live in urban areas than Spanish employed mothers $(34.58 \%$ and $46.95 \%$, respectively), are less likely to have university education $(24.34 \%$ and $38.38 \%$, respectively), have a lower (log) wage rate (2.05 and 2.85, respectively), and are less likely to work part-time $(3.20 \%$ and $12.10 \%$, respectively). Regarding differences in occupations, compared to employed mothers, self-employed mothers are more likely to work in "Management, business, financial" and "Natural resources, construction, maintenance", while those same mothers are less likely to work in "Professional and related", "Healthcare support", "Protective services", "Building and grounds cleaning and maintenance" and "Office and administrative support".

In summary, we find no statistically significant differences in the time devoted to Market Work, Child care, Household Production and Leisure, although we do find a statistically significant difference in Tertiary Activities, favoring the self-employed mothers. However, in this analysis, we need to control for other demographic and household characteristics, such as the number and age of the children, the wage rate, and occupation. For instance, Gimenez-Nadal and Sevilla-Sanz (2011) find that working mothers have leisure levels that are much lower than comparable working fathers or singles. Thus, such mothers may use self-employment as a way to reduce conflicting family and work pressures. 


\section{Empirical Strategy and Results}

\section{Empirical Strategy}

We condition the time allocation decisions of mothers on demographics. Thus, we estimate the following OLS model for each time use category (Market Work, Household Production, Tertiary Activities, Leisure and Child Care): ${ }^{9}$

$\mathrm{Y}_{\mathrm{i}}=\alpha+\gamma_{\text {Personal }}$ Personal $_{\mathrm{i}}+\gamma_{\text {family }_{\text {Family }}}+\beta_{1}$ Part-Time $_{\mathrm{i}}+\beta_{2}$ Self-Employed $_{\mathrm{i}}+\beta_{3}$ Occup $_{\mathrm{i}}+$
$+\beta_{4}$ Children Part-Time $_{\mathrm{i}}+\beta_{5}$ Children $^{*}$ Self-Employed $_{\mathrm{i}}+\beta_{6}$ Part-Time*Self-Employed $_{\mathrm{i}}+\gamma_{\mathrm{day}}$ Day $_{\mathrm{i}}+\xi_{\mathrm{i}}$

where $Y_{i}$ is the time use category for individual "i"; Personal ${ }_{i t}$ is a vector of personal characteristics (age, age squared, urban/rural, health status and civic status); Family is a vector of family characteristics (Number of children 0-2, Number of children 3-5, Number of children 6-12, Number of children 13-17, and Number of family members); Self_Employed is a "dummy" variable to control for self-employment status; Part_Time is a "dummy" variable to control for part-time status; and $\mathrm{Occup}_{i}$ is a vector of dummy variables that controls for occupation (type of work). Given previous evidence that self-employed women are more likely to have multiple children (Connelly, 1992; Caputo and Dolinsky, 1998; Boden, 1999), we include the interaction terms between the number and age of the children and being self-employed (and working part-time). Finally, we include an interaction term between "self-employment" and "working part-time", to avoid conflating part-time and self-employment status. ${ }^{10}$

\section{Results}

Table 2 shows the results of estimating an OLS regression for each dependent variable. We observe that Age and Age squared have statistically significant positive and negative associations, respectively, with the time devoted to Child Care, with these associations being statistically significant at the $1 \%$ level. Thus, age has an inverted ushaped effect on Child Care, with the maximum being reached at the age of 37 . This result is consistent with the life cycle of the family, in that, when children are young, the parents spend more time caring for them. Furthermore, Number of family members has a negative

\footnotetext{
${ }^{9}$ We have also used several additional indicators to take advantage of contextual information included in the survey, such as the information about who else was present during an activity, and where the activity occurred. However, there are data limitations, and these additional indicators add little to the analysis (available upon request).

${ }_{10}$ We do not include interaction terms between the number of children and 'part-time* self-employed', since the low percentage of 'part-time self-employed' mothers leads to multicolinearity problems. We estimate OLS regressions for each time use category, and we obtain robust estimates using the population weights included in the survey. Day ${ }_{i t}$ is a variable scaling the day of the week when the survey took place (ref.: Monday), and the omitted occupation is "Medical professionals". We do not show results for the day of the week and occupational dummies.
} 
association with the time devoted to Child Care, since an additional adult member in the household reduces the time devoted to Child Care by the mother by 10.06 minutes in a working day, with this association being statistically significant at the $1 \%$ level.

Education has statistically significant effects on the time devoted to both Market Work and Household Production. Thus, university education has a statistically significant negative association with the time devoted to Household Production at the 5\% level, with highly educated women devoting 25.98 fewer minutes to Household Production per working day than women with primary education. Furthermore, education has a statistically significant positive association with the time devoted to Market Work, with highly and medium educated women devoting 24.96 (statistically significant at the 10\% level) and 35.75 (statistically significant at the $5 \%$ level) more minutes to Market Work activities per working day, respectively.

The number of children has important effects on the allocation of time in a working day. In the case of full-time employed mothers (reference group), children under 13 have statistically significant positive associations with the time devoted to Child Care, with the highest effect being found for children under age 3, where an additional child increases the time devoted to Child Care by 87.40 minutes per day, and the lowest effect is found for the number of children between 6 and 12 years, where an additional child increases the time devoted to Child Care by 12.63 minutes per day. The number of children under 18 has statistically significant negative associations with the time devoted to Market Work, with the greatest effect being found for children under 3, while the number of children between 6 and 17 has statistically significant positive correlations with the time devoted to Household Production, with the greatest effect being found for children between 13 and 17 years old. All these associations are statistically significant at the $5 \%$ level.

Regarding the effects of children for part-time employed mothers, such effects are similar to the case of full-time employed mothers, the only statistically significant difference at the $5 \%$ level being that children under age 3 have a negative association with the time devoted to Household Production, decreasing the time devoted to these activities by 52.95 minutes per working day. In the case of full-time self-employed mothers, children have similar effects to the case of full-time employed mothers, with the difference being that the number of children between 6 and 12, and between 13 and 17, have positive associations with the time devoted to Market Work; and the number of children between 
13 and 17 has a negative association with the time devoted to Leisure, with these associations being statistically significant at the $5 \%$ level.

We now turn to the variables controlling for work status. On the one hand, compared to full-time employed mothers, working part-time has a statistically significant negative association with the time devoted to Market Work (150.52 fewer minutes per working day), while it has a statistically significant positive association with the time devoted to Housebold Production at the 1\% level (113.21 more minutes per working day). Hence, we find a trade-off between the time devoted to Market Work and Household Production in a working day with part-time employment of mothers. On the other hand, being full-time self-employed has a statistically significant negative association with the time devoted to Market Work (97.34 fewer minutes per working day), and statistically significant positive associations with the time devoted to Tertiary Activities (43.17 more minutes per working day) and Leisure (47.32 more minutes per working day), with these associations being statistically significant at the 5\% level. Finally, compared to full-time employed mothers, being part-time self-employed has a statistically significant positive association with the time devoted to Tertiary Activities at the 5\% level, with part-time selfemployed mothers devoting 101.40 more minutes per day to Tertiary Activities than fulltime employed mothers.

The analysis of aggregates of time use reveals that, when we control for observed heterogeneity, self-employed mothers devote less time to Market Work, and more time to Tertiary Activities and Leisure than full-time employed mothers in a working day. These results are consistent with Hyytinen and Ruskanen (2007), who find that self-employed people get more sleep, and also with Biddle and Hamermesh (1990), who find that sleep is very much a choice variable. This evidence is also in line with Reynolds (2005), who finds that 'work-life conflict makes women want to decrease the number of hours they work whether the conflict originates at home or at work.' Given the desire to reduce the amount of work hours for mothers who are dealing with conflicting family and work pressures, self-employment appears to allow for such reduction.

Furthermore, prior research has shown that the number of children in the home is positively related to the probability of self-employment, at least among women, as is the number of young children (Connelly, 1992; Caputo and Dolinsky, 1998; Boden, 1999). Similarly, the number of children at home is correlated with home-based work in the United States (Edwards and Field-Hendrey, 1996). From this evidence, authors have inferred that self-employment is chosen in order to spend more time with the children. 


\section{Self-employment and Child Care}

One of the arguments for the hypothesized relationship between selfemployment and child care is that an individual in self-employment is perceived as having greater control over the timing of work (flexible hours), so the self-employed mother may be able to work during school hours, after the children have gone to bed, at odd shifts or part-time, when a spouse or other family member is available to care for the children. In such a case, we would observe a different timing in Child Care and Household Production, given that self-employed mothers with children are able to devote time to these activities at times when they otherwise could not, if they were working for a firm. Thus, we now analyze the timing of such activities throughout a working day, comparing employed and self-employed mothers.

For this analysis, we follow Hamermesh (1999) and we construct the series $T_{i b}$, where "i" refers to the individual, and " $t$ " refers to the time band of the day. We divide the 24 hours of the working day into 24 time bands $(t=1,2,3 \ldots 24)$, and we compute the amount of time devoted to the reference activity (Market Work, Child Care...) in each time band " $\mathrm{t}$ ". We estimate the following OLS model for each time band:

$$
\begin{aligned}
& \mathrm{T}_{\mathrm{it}}=\alpha+\gamma_{\text {age }} \text { Age }_{\mathrm{i}}+\gamma_{\text {educ }} \text { Educ }_{\mathrm{i}}+\gamma_{\text {family }_{\text {Family }}}+\beta_{1} \mathrm{~T}_{\mathrm{i}}+\beta_{2} \text { Self_Employed }_{\mathrm{i}}+ \\
& +\beta_{3} \text { Occup }_{\mathrm{i}}+\beta_{4} \text { Partner }_{\mathrm{i}}+\gamma_{\text {day }} \text { Day }_{\mathrm{i}}+\xi_{\mathrm{it}}
\end{aligned}
$$

where $A g e_{i}$ controls for the age of the individual 'i' (and its square), Educ controls for education (ref.: primary education), Family is a vector of family characteristics (Number of children 0-2, Number of children 3-5, Number of children 6-12, and Number of Family Members, married), $T_{i}$ is the total amount of time devoted to the reference activity for the individual

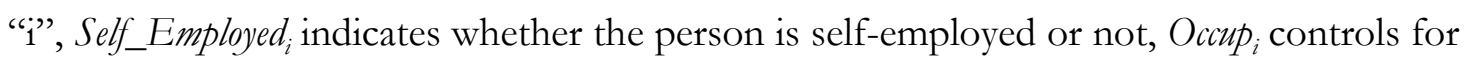
the occupation of the individual, Partner ${ }_{i}$ is a vector of partner's work characteristics 
(partner is in a working day, and partner is self-employed), and Day ${ }_{i}$ is a vector scaling the day of the week (ref.: Monday). ${ }^{11}$

Graph 1 shows the estimated coefficients of the self-employment dummy on the timing regressions for Market Work, Household Production, Child Care and Aggregate Housework (Housebold Production plus Child Care). First, we observe that there are statistically significant negative associations between being self-employed and the timing of Market Work, Household Production and Child Care from 6 a.m. to 11 a.m., from 6 a.m. to 7 a.m., and from 6 a.m. to 8 a.m., respectively. At the same time, we find statistically significant positive associations between being self-employed and Household Production and Child Care from 7 a.m. to 11 a.m., and from 9 a.m. to 12 a.m., respectively. Second, we find that being self-employed has statistically significant negative associations with Market Work from 1 p.m. to 3 p.m., while it has significant positive associations with Household Production and Child Care in the same period. Third, being self-employed has statistically significant positive associations with Market Work from 5 p.m. to 9 p.m., while it has statistically significant negative associations with both Household Production and with Child Care from 5 p.m. to 7 p.m.

Thus, we find that, compared to employed mothers, self-employed mothers devote 11.40 and 9.26 percentage points more of their time to Child care (6.36 more minutes out of 55.767 minutes, see Table 1) and Household Production (19.30 more minutes out of 208.48 minutes, see Table 1), respectively, in the period from 8 a.m. to 3 p.m. Additionally, we find that self-employed mothers devote less time to Market Work in the morning and afternoon (e.g., from 8 a.m. to 3 p.m.) compared to employed mothers, since they devote 10.54 percentage points less time to these activities (41.97 fewer minutes out of 398.27 minutes). Second, compared to employed mothers, we find that self-employed mothers devote 8.75 and 5.99 percentage points less of their time to Child care and Household Production in the evening (e.g., from 5 p.m. to 9 p.m.), respectively, while self-employed mothers devote 11.23 percentage points more time to Market Work in the evening compared to employed mothers.

These results are consistent with the hypothesized relationship between selfemployment and child care, that self-employed mothers are perceived as having greater

\footnotetext{
11 Since we find differences in the amount of time devoted to Market Work, Tertiary Activities and Leisure between employed and self-employed mothers, we need to control for such differences in our timing regressions, so we include the total time devoted to each activity. Controlling for whether the husband/partner is in a working day or not is also important, since the fact that the husband/partner is in a working day may require the mother to devote more time to Cbild Care, and less time to Market Work during the morning, than when the husband/partner does not have to work.
} 
control over the timing of work (flexible hours), so they may devote more time to the children in the mornings and afternoons, and they more easily work odd shifts, when a spouse or other family member is available to care for the children. Hyytinen and Ruskanen (2007) also find that the self-employed with younger children are more likely to work after 5 p.m., when the majority of communal day-care centers close. Additionally, in the United States, Stewart and Allard (2008) find that part-time employment allows mothers to spend more time with their children during the mornings and afternoons, compared to full-time employment.

Given the hypothesized relationship between child care and self-employment, that self-employed mothers may more easily work odd shifts, when a spouse or other family member is available to care for the children, we now analyze the correlations between the timing of Child Care for men and the timing of Market Work of their employed spouses. To that end, we regress, for each time band, the proportion of time devoted to Child Care by men in the reference time band, conditioned on whether their female partners devoted time to Market Work (1) or not (0) during the same time band. For instance, considering the first time band of the day (12 p.m. to 1 a.m.), we estimate the probability (in percentage points) of devoting time to Child Care by men, conditioned on own demographics, family characteristics, total own time devoted to Child Care, own self-employment status, and whether the wife is devoting any time to Market Work (1) or not $(0)$ in this time band.

Graph 2 shows the associations between Child Care of men, and Market Work of their female partners. We find statistically significant positive associations from 7 a.m. to 10 a.m., from 2 p.m. to 3 p.m., and from 5 p.m. to 7 p.m., with these associations being statistically significant at the $5 \%$ level. Thus, we find that, if the mother is devoting time to Market Work activities, the spouses of such working mothers are 4.90, 7.30, 2.00, 3.10, 4.30, 3.20 and 3.70 percentage points more likely to be devoting time to Child Care from 7 to 8 a.m., 8 to 9 a.m., 9 to 10 a.m., 2 to 3 p.m., 5 to 6 p.m., 6 to 7 p.m. and 7 to 8 p.m., respectively. Thus, we find complementarities between the time devoted to child care activities by men and the time devoted to market work activities by their spouses, since men devote more time to child care activities, if their spouses are working, than if their spouses are not, in most of the hours in the middle of the day.

Given such positive correlations, and since we find that, compared to employed mothers, self-employed mothers devote less time to market work activities from 8 a.m. to 11 a.m. and from 1 p.m. to 3 p.m., and more time from 5 p.m. to 9 p.m., we interpret 
these results as indicating that the spouses of self-employed mothers are more likely to devote time to child care activities from 5 p.m. to 7 p.m., and less likely to do so from 8 a.m. to 11 a.m. and from 1 p.m. to 3 p.m., compared to the spouses of employed mothers.

Thus, our results on timing support the hypothesized relationship between child care activities and self-employment. Mothers may choose self-employment as a way to have greater control over the timing of work, so that the self-employed mother may be able to work at odd shifts, when the spouse is available to care for the children.

\section{Conclusions}

This paper deals with an important subject for policy decision-making, that is, how working conditions and work status interact with family responsibilities, especially with the time devoted to child care. We focus on self-employment as a possible way for mothers to have greater control over their allocation of time, using time diary data from the Spanish Time Use Survey 2002-2003 (STUS).

Despite differences in the time devoted to Market Work, Tertiary Activities and Leisure between employed and self-employed mothers in a working day, we find no support for the hypothesis that self-employed mothers spend more time caring for children than do employed mothers. However, we do find that self-employed mothers devote more time to Child Care and less time to Market Work during the morning and afternoon, and less time to Child Care and more time to Market Work during the evening, compared to employed mothers. We also find complementarities between the time devoted to Child Care and Market Work by the members of the couple.

These differences in the timing of activities between employed and self-employed mothers, together with the complementarities between the time allocations of both members of the couple, are consistent with the hypothesis that self-employed mothers have greater control over the timing of work compared to employed mothers, since they are able to shift part of their market work responsibilities to the evening, when the spouse is available to care for the children. Given these differences, self-employment appears to be one significant strategy to improve the balance between work and family responsibilities. These findings are in accordance with the European Union employment agenda for 2010, established in Lisbon in 2000, where one target was increasing female 


\section{REFERENCES}

Aguiar, M., and E. Hurst (2007), "Measuring Trends in Leisure: The Allocation of Time Over Five Decades," Quarterly Journal of Economics, 122(3), 969-1006.

Aliaga, C. (2006), "How is the time of women and men distributed in Europe?" Statistics in Focus, Population and Social Conditions N 4/2006, EUROSTAT.

Allen, T., D. Herst, C. Bruck, and M. Sutton (2000), "Consequences associated with work-to-family conflict: A review and agenda for future research," Journal of Occupational Health Psychology, 5, 278-308.

Altman, M. (2001), “A Behavioral model of labor supply: casting some light into the black box of income-leisure choice," The Journal of Socio-Economics, 33, 199-219.

Arai, B. (2008), "Self-Employment as a Response to the Double Day for Women and Men in Canada," Canadian Review of Sociology, 37, 125-142.

Bianchi, S.M., M.A. Milkie, L.C. Sayer, and J.P. Robinson (2000), "Is Anyone Doing the Housework? Trends in the Gender Division of Household Labor," Social Forces, 79, 191-228.

Biddle, J. and D. Hamermesh (1990), "Sleep and the Allocation of Time," Journal of Political Economy, 98(5), 922-943.

Bittman, M. and J. Wajcman (2000), “The Rush Hour: The Character of Leisure Time and Gender Equity," Social Forces, 79(1), 165-189.

Boden, R. J. (1999), “Flexible Working Hours, Family Responsibilities, and Female Selfemployment," American Journal of Economics and Sociology, 58(1), 71-83. 
Bonke, J., N. Datta-Gupta and N. Smith (2004), “Timing and Flexibility of Housework and Men's and Women's Wages," in Contributions to Economic Analysis, Vol. 271, D.S. Hamermesh and G.A. Pfann (eds.), Elsevier Press, 2004.

Burda, M., D. Hamermesh and P. Weil (2008), “The Distribution of Total Work in the Us and EU," in Tito Boeri, Michael Burda, Francis Kramarz (eds.), Working Hours and Job Sharing in the EU and USA: Are Americans Crazy? Are Europeans Lazy? Oxford Univ. Press, 2008.

Buttner, E, (1993), "Female Entrepreneurs: how far have they come?" Business Horizons, 2, 59-65.

Byron, K. (2005), “A meta-analytic review of work-family conflict and its antecedents," Journal of Vocational Behavior, 67, 169-198.

Caputo, R.K. and A. Dolinsky (1998), “Women's Choice to Pursue Self-Employment: The Role of Financial and Human Capital of Household Members," Journal of Small Business Management, July, 8-17.

Coltrane, S (2000), "Research on household labor: Modeling and measuring the social embeddedness of routine family work," Journal of Marriage and Family, 62, 12081233.

Connelly, R. (1992), “Self-employment and Providing Child Care,” Demograpby, 29(1), 1729.

Del Boca, D. (2002), “Low Fertility and Labour Force Participation of Italian Women: Evidence and Interpretations", OECD Labour Market and Social Policy Occasional Papers, N. 61, OECD Publishing

DeMartino, R. and R. Barbato (2003), "Differences between women and men MBA entrepreneurs: Exploring family flexibility and wealth creation as career motivators," Journal of Business Venturing, 18(5), 815-832.

Edwards, L. N. and E. Field-Hendrey (1996), "Home-Based Workers: Data from the 1990 Census of Population," Monthly Labor Review, 119(11).

Fisher, K. M. Egerton, J.I. Gershuny and J. P. Robinson (2007), "Gender Convergence in the American Heritage Time Use Study (AHTUS)," Social Indicators Research 82(1), $1-33$. 
Gauthier, A. H., T. Smeeding and F. Furstenberg (2004), "Are Parents Investing Less Time in Children? Trends in Selected Industrialized Countries," Population and Development Review, 30, 647-671.

Gimenez-Nadal, I., and A. Sevilla-Sanz (2011), “The Time-Crunch Paradox," Social Indicators Research, in press (10.1007/s11205-010-9689-1).

Goffee, R. and R. Scase (1983), “Business Ownership and Women’s Subordination: A Preliminary Study of Female Proprietors," The Sociological Review, 31, 625-648.

Grzywacz. J., and B. Bass. (2003), "Work, Family, and Mental Health: Testing Different Models of Work-Family Fit," Journal of Marriage and Family, 65, 248 - 261

Hamermesh, D. (1998), "When We Work," The American Ecomomic Review, Papers and Proceedings of the hundred and Tenth Annual Meeting of the American Economic Association, 88(2), 321-325.

Hamermesh, D. (1999), “The timing of work over time," The Economic Journal, 109(1), 3766.

Hersh, J. (2009), "Home Production and Wages: Evidence from the American Time Use Survey" Review of Economics of the Household, 9(2), 159-178

Hildebrand, V. and D. Williams (2003), "Self-employment and Caring for Children: Evidence from Europe," IRISS Working Paper Series 2003-06.

Hochschild, A. R., and A. Machung (1989), The Second Shift: Working Parents and the Revolution at Home (New York: Viking).

Hochschild, A. R. (1997), The Time Bind: When Work Becomes Home and Home Becomes Work (New York: Metropolitan Books).

Hundley, G. (2000), "Male/Female Earnings Differences in Self-Employment: The Effects of Marriage, Children, and the Household Division of Labor," Industrial and Labor Relations Review, 54(1), 95-114.

Hyytinen, A. and O. P. Ruskanen (2007), "Time Use of the Self-Employed," Kyklos, 60(1), 105-122.

Kalenkoski, C., D. Ribar, and L. Stratton (2005), "Parental Child Care in Single Parent, Cohabiting, and Married Couple Families: Time Diary Evidence from the United Kingdom," American Economic Review papers and proceedings, May. 
Kaplan, E. (1988), Women entrepreneurs: Constructing a framework to examine venture success and business failure (Frontiers of Entrepreneurship Research, Wellesley, MA: Babson College).

Kossek, E., and C. Ozeki (1999), "Work-family conflict, policies, and the job-life satisfaction relationship: A review and directions for organizational behavior human resources research," Journal of Applied Psychology, 83, 139-149.

Layard, R. (2005), Happiness: Lessons from a new Science (The Brookings Institution, Allen Lane, London).

Lombard, K. (2007), "Female self-employment and demand for flexible, nonstandard work schedules," Economic Inquiry, 39, 214-237.

Loscocoo, K. (1997), “Work-Family Linkages among Self-Employed Women and Men,” Journal of Vocational Behavior, 50, 204-226.

Mattingly, M. J., and S. M. Bianchi (2003), "Gender differences in the quantity and quality of free time: The US experience," Social Forces, 81, 999-1029.

Mattingly, M. J., and L. C. Sayer (2006), "Under Pressure: Gender Differences in the Relationship Between Free Time and Feeling Rushed," Journal of Marriage and Family, 68, 205-221.

Mesmer-Margnus, J. R., and C. Viswesvaran (2005a), "Convergence between measures of work-to-family and family-to-work conflict: A meta-analytic examination," Journal of Vocational Behavior, 67, 215-232.

Mesmer-Margnus, J. R., and C. Viswesvaran (2005b), "How family-friendly work environments affect work/family conflict: A meta-analytic examination," Journal of Labor Research, 27, 555-574.

Netemeyer, R. G., J. S. Boles, and R. McMurrian (1996), “Development and validation of work-family conflict and family-work conflict scales," Journal of Applied Psychology, 81, 400-410.

Noonan, M. (2004), “The Impact of Domestic Work on Men's and Women's Wages,” Journal of Marriage and Family, 63, 1134-1145.

OECD (2005), Employment Outlook 2005.

Presser, H. B. (1989), "Can We Make Time for Children? The Economy, Work Schedules, and Child Care," Demography, 26(4), 523-543. 
Poortman, A-R., and T. van der Lippe (2009), “Attitudes Toward Housework and Child Care and the Gendered Division of Labor," Journal of Marriage and Family, 71, 526541.

Reynolds, J. (2005), "In the Face of Conflict: Work-Life Conflict and Desired Work Hour Adjustments," Journal of Marriage and Family, 67, 1313-1331.

Robinson, J.P. and G. Godbey (1997), Time for Life: The Surprising Ways Americans Use their Time (University Park, Pennsylvania: The Pennsylvania State University Press).

Sayer, L. C. (2005), “Gender, time, and inequality: Trends in women's and men's paid work, unpaid work and free time," Social Forces, 84, 285-303.

Schor, J. (1991), The Overbooked American: The Unexpected Decline of Leisure (New York: Basic Books).

Scott, C.E. (1986), "Why more women are becoming entrepreneurs," Journal of Small Business Management, 24, 37-44.

Sevilla-Sanz, A., J.I. Gimenez-Nadal and C. Fernandez (2010), "Gender Roles and the Household Division of Unpaid Work: Evidence from the Spanish Time Use Survey" Feminist Economics, 16(4), 137-184.

Stewart, J. and M. D. Allard (2008), "How Does Employment Affect the Timing of Time with Children?” U.S Burean of Labor Statistics, Working Paper N 419, May 2008.

Väisänen, P. (2006), "Mean of episode lenghts as a quality indicator of time use diaries," Paper presented at the 28th IATUR Annual Conference, Copenhagen. 
Table 1. Unconditional Means for Employed and Self-Employed Mothers 1,2,3,4

\begin{tabular}{|c|c|c|c|c|c|c|}
\hline \multirow{3}{*}{ Panel A: Time UseVariables } & \multicolumn{2}{|c|}{$(1)$} & \multicolumn{2}{|c|}{ (2) } & \multirow{2}{*}{$\begin{array}{c}(3) \\
\text { Diff. Self-Employed - } \\
\text { Employed } \\
\end{array}$} & \multirow{3}{*}{$\begin{array}{c}(4) \\
p \text {-value } \\
\text { Diff. }\end{array}$} \\
\hline & \multicolumn{2}{|c|}{ Self-employed } & \multicolumn{2}{|c|}{ Employed } & & \\
\hline & Mean & S.D. & Mean & S.D. & & \\
\hline Market Work & 398.274 & $(14.396)$ & 394.345 & $(3.935)$ & 3.930 & 0.790 \\
\hline Child Care & 55.767 & $(6.745)$ & 66.626 & $(2.281)$ & -10.860 & 0.130 \\
\hline Household Production & 208.482 & $(9.997)$ & 205.884 & (3.168) & 2.600 & 0.800 \\
\hline Tertiary Activities & 599.273 & $(7.515)$ & 582.344 & $(2.473)$ & 16.930 & 0.030 \\
\hline Leisure & 142.298 & $(8.224)$ & 139.126 & $(2.730)$ & 3.170 & 0.710 \\
\hline \multirow[t]{2}{*}{ Panel B: Explanatory Variables } & \multicolumn{2}{|c|}{ Self-employed } & \multicolumn{2}{|c|}{ Employed } & $\begin{array}{c}\text { Diff. Self-Employed - } \\
\text { Employed } \\
\end{array}$ & $\begin{array}{c}p \text {-value } \\
\text { Diff. }\end{array}$ \\
\hline & Mean & S.D. & Mean & S.D. & & \\
\hline Age & 39.105 & $(0.501)$ & 38.237 & $(0.182)$ & 0.870 & 0.100 \\
\hline Number of family members & 3.959 & $(0.065)$ & 3.856 & $(0.023)$ & 0.100 & 0.140 \\
\hline Urban household & 34.574 & $(3.744)$ & 46.959 & $(1.429)$ & -12.390 & 0.000 \\
\hline Health status & 1.897 & $(0.057)$ & 1.850 & $(0.019)$ & 0.050 & 0.430 \\
\hline Married (vs. cohabiting) & 97.007 & $(1.353)$ & 96.214 & $(0.565)$ & 0.790 & 0.590 \\
\hline University education & 24.343 & $(3.407)$ & 38.380 & $(1.397)$ & -14.040 & 0.000 \\
\hline Secondary education & 62.243 & $(3.819)$ & 50.208 & $(1.433)$ & 12.040 & 0.000 \\
\hline Log hourly wage rate & 2.051 & $(0.072)$ & 2.848 & $(0.026)$ & -0.800 & 0.000 \\
\hline Number of children & 1.550 & $(0.058)$ & 1.566 & $(0.019)$ & -0.020 & 0.800 \\
\hline Number of children $0-2$ & 0.220 & $(0.034)$ & 0.222 & $(0.013)$ & 0.000 & 0.950 \\
\hline Number of children 3-5 & 0.217 & $(0.036)$ & 0.275 & $(0.014)$ & -0.060 & 0.140 \\
\hline Number of children 6-12 & 0.584 & $(0.057)$ & 0.631 & $(0.020)$ & -0.050 & 0.430 \\
\hline Number of children 13-17 & 0.531 & $(0.050)$ & 0.438 & $(0.017)$ & 0.090 & 0.080 \\
\hline Working part-time & 3.18 & $(1.35)$ & 11.14 & $(0.87)$ & -8.050 & 0.000 \\
\hline Management, business, financial & 30.980 & $(3.645)$ & 4.291 & $(0.565)$ & 26.690 & 0.000 \\
\hline Professional and related & 17.966 & (3.016) & 27.734 & $(1.279)$ & -9.770 & 0.000 \\
\hline Healthcare support & 4.198 & $(1.595)$ & 9.635 & $(0.826)$ & -5.440 & 0.000 \\
\hline Protective service & 0.000 & $(0.000)$ & 0.597 & $(0.232)$ & -0.600 & 0.010 \\
\hline Food preparation and serving related & 5.519 & $(1.829)$ & 5.921 & $(0.682)$ & -0.400 & 0.840 \\
\hline Building and grounds cleaning and maintenance & 3.277 & $(1.469)$ & 14.048 & $(0.995)$ & -10.770 & 0.000 \\
\hline Personal care and service & 5.432 & $(1.780)$ & 2.961 & $(0.483)$ & 2.470 & 0.180 \\
\hline Sales and related & 10.871 & $(2.461)$ & 8.354 & $(0.810)$ & 2.520 & 0.330 \\
\hline Office and administrative support & 3.228 & $(1.429)$ & 13.609 & $(0.998)$ & -10.380 & 0.000 \\
\hline Natural resources, construction, maintenance & 11.402 & $(2.385)$ & 3.569 & $(0.515)$ & 7.830 & 0.000 \\
\hline Production, transportation, material moving & 7.127 & $(2.086)$ & 9.144 & $(0.836)$ & -2.020 & 0.370 \\
\hline
\end{tabular}

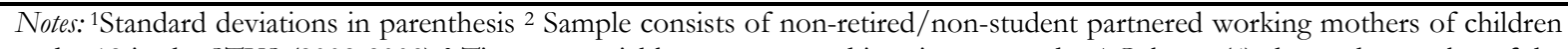
under 18 in the STUS (2002-2003) ${ }^{3}$ Time use variables are measured in minutes per day ${ }^{4}$ Column (4) shows the p-value of the differences, with a p-value lower than 0.05 meaning that the difference is statistically significant at the $5 \%$ level. 
Table 2. Time Use Regressions for Working Mothers in Working Days 1,2,3,4

\begin{tabular}{|c|c|c|c|c|c|}
\hline \multirow[b]{2}{*}{ Minutes per day } & $(1)$ & (2) & (3) & (4) & (5) \\
\hline & Market Work & $\begin{array}{c}\text { Hhld. } \\
\text { Production }\end{array}$ & $\begin{array}{c}\text { Tertiary } \\
\text { Activities }\end{array}$ & Leisure & Chidcare \\
\hline \multirow[t]{2}{*}{ Age } & -6.419 & 3.200 & -5.625 & 0.049 & $8.366^{* * *}$ \\
\hline & $(6.052)$ & $(4.727)$ & $(4.268)$ & (3.732) & $(1.970)$ \\
\hline \multirow[t]{2}{*}{ Age squared } & 7.559 & -1.583 & 5.953 & 0.062 & $-11.297 * * *$ \\
\hline & (7.823) & (6.323) & (5.334) & $(4.803)$ & (2.419) \\
\hline \multirow[t]{2}{*}{ Number of family members } & 7.896 & -1.135 & 5.176 & -2.147 & $-10.057 * * *$ \\
\hline & $(6.746)$ & (5.866) & $(4.531)$ & $(4.455)$ & $(1.863)$ \\
\hline \multirow[t]{2}{*}{ Urban household } & -2.066 & $-10.447 *$ & 0.814 & -3.522 & $6.060 *$ \\
\hline & (7.499) & $(6.084)$ & $(4.829)$ & (5.099) & $(3.542)$ \\
\hline \multirow[t]{2}{*}{ Health status } & -8.222 & 5.046 & 2.019 & -1.817 & 0.320 \\
\hline & (5.546) & (4.655) & (3.611) & (3.983) & $(2.375)$ \\
\hline \multirow[t]{2}{*}{ Married (ref: cohabiting) } & -7.448 & -5.236 & -6.689 & 0.820 & 12.857 \\
\hline & (20.414) & $(16.870)$ & (11.429) & (11.703) & (8.896) \\
\hline \multirow[t]{2}{*}{ University education } & $24.956 *$ & $-25.978 * *$ & -1.536 & 5.750 & 7.501 \\
\hline & (15.093) & $(12.710)$ & (9.386) & $(10.576)$ & $(6.235)$ \\
\hline \multirow[t]{2}{*}{ Secondary education } & $35.752 * * *$ & -11.206 & $-13.659 *$ & -6.014 & 0.463 \\
\hline & $(12.441)$ & (11.125) & (8.003) & (8.955) & $(4.771)$ \\
\hline \multirow[t]{2}{*}{ Log hourly wage rate } & (3.310) & $(4.784)$ & (1.989) & $(0.601)$ & $(2.261)$ \\
\hline & (5.279) & (3.974) & (3.111) & (3.523) & $(2.061)$ \\
\hline \multirow[t]{2}{*}{ Number of children $0-2$} & $-42.483^{* * *}$ & 2.251 & $-16.516^{*}$ & $-22.115^{* *}$ & $87.396 * * *$ \\
\hline & $(12.584)$ & (10.939) & (8.766) & (8.708) & $(7.140)$ \\
\hline \multirow[t]{2}{*}{ Number of children 3-5 } & $-21.232 *$ & 2.462 & -11.442 & -11.663 & $42.215^{* * *}$ \\
\hline & (11.140) & $(9.360)$ & (7.538) & (7.527) & $(5.682)$ \\
\hline \multirow[t]{2}{*}{ Number of children 6-12 } & $-31.073^{* * *}$ & $24.922 * * *$ & -4.061 & 3.179 & $12.626^{* * *}$ \\
\hline & $(8.380)$ & $(7.300)$ & (5.569) & $(6.121)$ & (3.657) \\
\hline \multirow[t]{2}{*}{ Number of children $13-17$} & $-25.212 * *$ & $29.473 * * *$ & -1.702 & 12.175 & $-7.831 * *$ \\
\hline & $(10.350)$ & (8.552) & (6.849) & (7.765) & (3.595) \\
\hline \multirow[t]{2}{*}{ Number of children $0-2 *$ Working part-time } & 38.975 & $-52.947 * *$ & -5.878 & 1.436 & -7.838 \\
\hline & $(29.251)$ & $(22.371)$ & $(18.974)$ & $(22.567)$ & $(15.430)$ \\
\hline \multirow[t]{2}{*}{ Number of children $3-5 *$ Working part-time } & 29.359 & $-45.360 *$ & -10.247 & -0.607 & 15.318 \\
\hline & $(28.130)$ & $(23.276)$ & (14.429) & $(20.773)$ & $(13.771)$ \\
\hline \multirow[t]{2}{*}{ Number of children $6-12 *$ Working part-time } & -0.011 & -24.305 & 9.050 & -12.047 & 7.771 \\
\hline & $(22.057)$ & $(18.348)$ & $(10.493)$ & $(16.143)$ & $(8.320)$ \\
\hline \multirow[t]{2}{*}{ Number of children $13-17 *$ Working part-time } & 18.568 & -35.143 & -10.509 & 19.654 & -10.039 \\
\hline & $(21.018)$ & $(23.683)$ & (11.349) & $(25.478)$ & (9.038) \\
\hline \multirow[t]{2}{*}{ Number of children $0-2 *$ Working self-employed } & 38.304 & -7.256 & $-36.071^{*}$ & -29.589 & 29.254 \\
\hline & $(34.718)$ & (24.099) & $(21.082)$ & $(19.287)$ & $(22.062)$ \\
\hline Number of children $3-5 *$ Working self-employed & 39.281 & -3.445 & -20.682 & -8.655 & -8.526 \\
\hline & $(32.301)$ & $(23.766)$ & $(16.315)$ & $(18.204)$ & $(13.483)$ \\
\hline Number of children $6-12 *$ Working self-employed & $43.088 * *$ & -4.559 & -16.655 & $-19.777 *$ & -5.500 \\
\hline & $(20.594)$ & $(15.314)$ & $(12.932)$ & $(12.008)$ & $(6.800)$ \\
\hline Number of children $13-17 *$ Working self-employed & $73.321 * * *$ & -25.133 & -15.296 & $-37.838 * *$ & 2.629 \\
\hline & $(24.274)$ & $(18.602)$ & (12.373) & $(15.222)$ & (7.449) \\
\hline Working part-time & $-150.523^{* * *}$ & $113.214^{* * *}$ & 21.205 & 38.088 & 12.915 \\
\hline & $(31.425)$ & $(27.417)$ & $(16.105)$ & $(24.403)$ & $(13.592)$ \\
\hline Working self-employed & $-97.339 * * *$ & 26.362 & $43.174 * *$ & $47.316^{* *}$ & -0.616 \\
\hline & $(31.272)$ & $(22.635)$ & $(17.872)$ & $(21.356)$ & $(10.013)$ \\
\hline Working self-employed*Working part-time & -68.887 & 30.385 & $58.225^{* *}$ & -41.848 & 16.331 \\
\hline & $(58.027)$ & $(69.703)$ & $(29.160)$ & $(29.914)$ & $(22.054)$ \\
\hline Constant & $522.751^{* * *}$ & 49.013 & $748.116^{* * *}$ & $215.882^{* * *}$ & $-125.244 * * *$ \\
\hline & $(120.861)$ & $(93.006)$ & $(84.432)$ & $(76.773)$ & $(42.747)$ \\
\hline Observations & 1,433 & 1,433 & 1,433 & 1,433 & 1,433 \\
\hline R-squared & 0.139 & 0.121 & 0.069 & 0.101 & 0.436 \\
\hline
\end{tabular}


Graph 1. Timing of Market Work, Housework, Child care and Leisure, Mothers 1,2,3

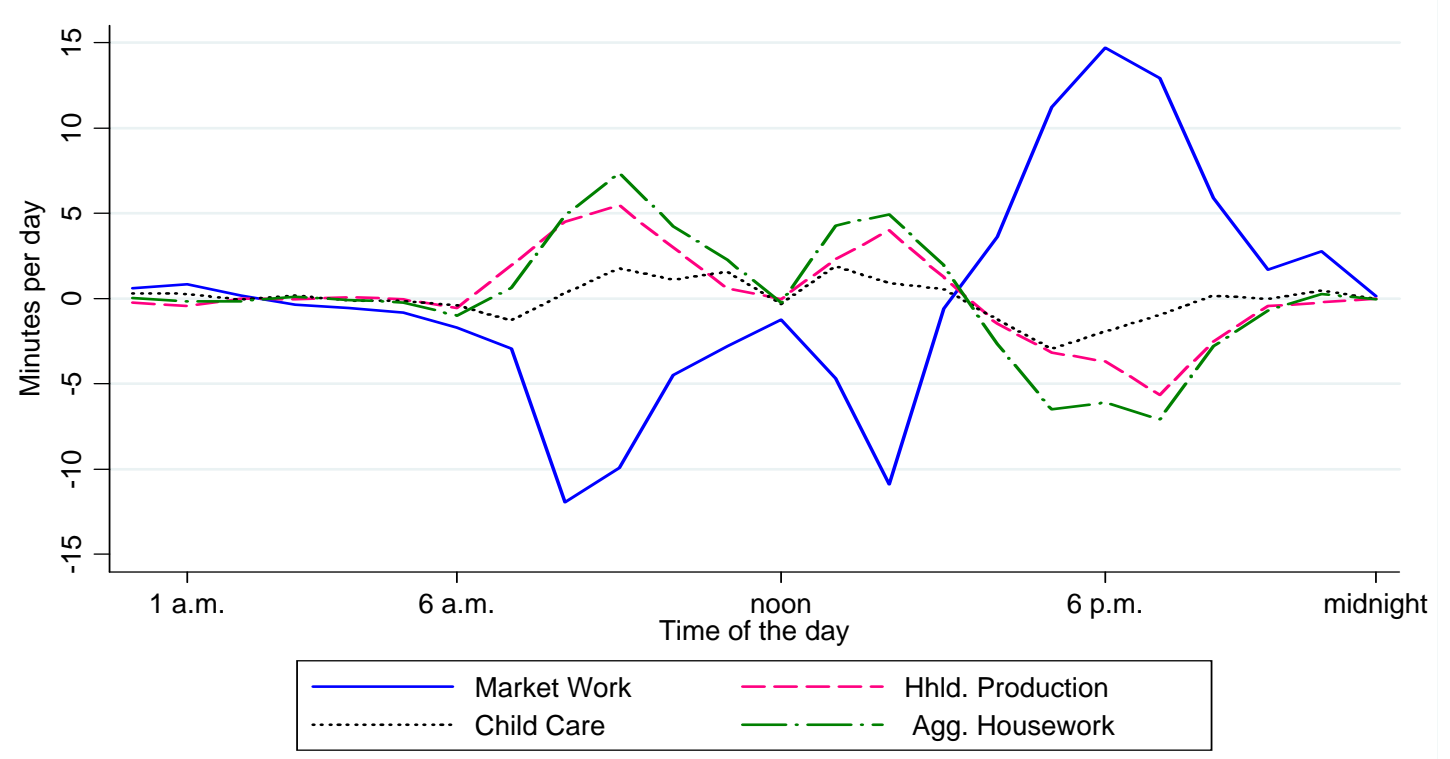

Notes: ${ }^{1}$ This figure plots the coefficients of self-employment dummy from regressions of timing of activities on age, day-of-week, family composition, mother's occupation and spouse's working controls ${ }^{2}$ Sample consists of non-retired/non-student partnered working mothers of children under 18 in the STUS (2002-2003) ${ }^{3}$ Each value represents timing-deviations from the employed mothers, conditional on demographics. 
Graph 2. Correlations between Market Work of Mothers and Child Care of Fathers 1,2,3,4

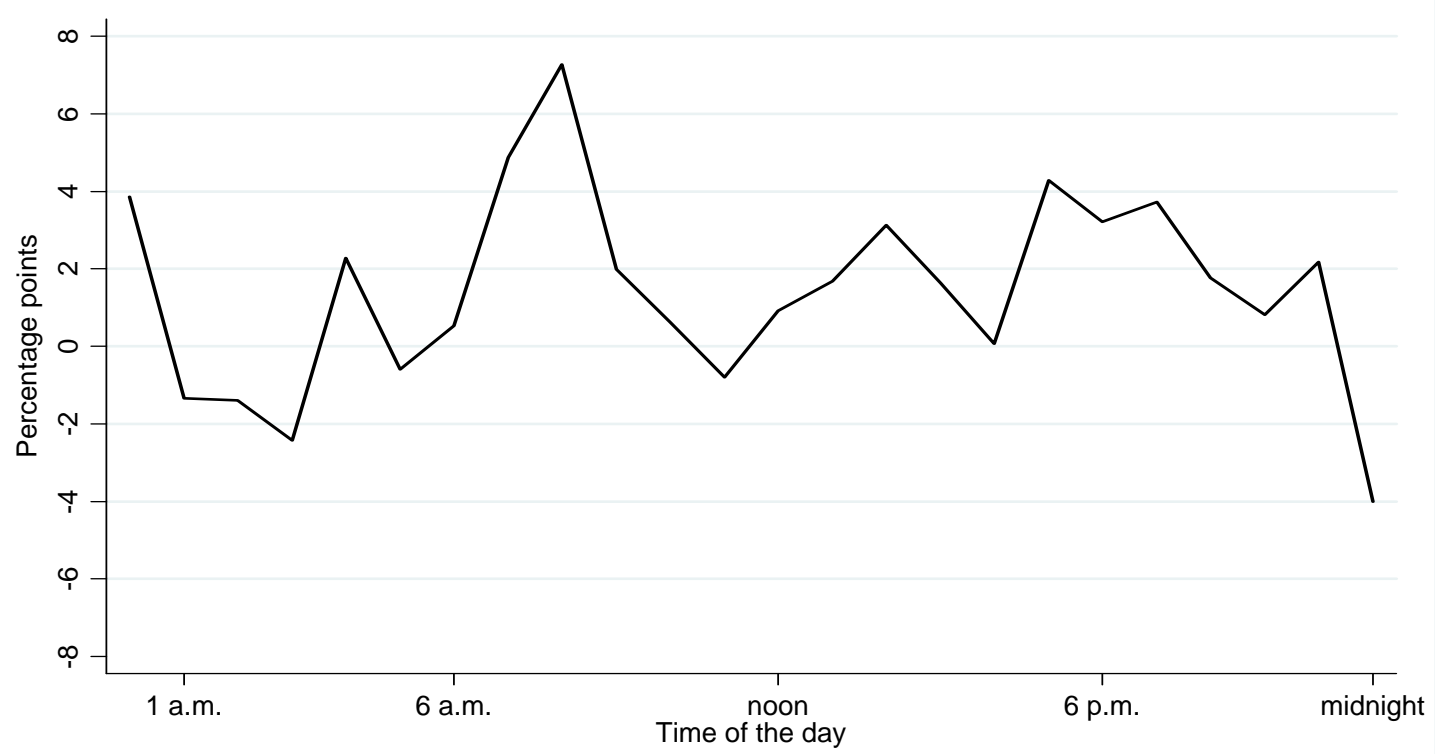

Notes: 1 This figure plots the coefficients of women's participation in Market Work activities $(1=\mathrm{yes} ; 0=\mathrm{no})$ on men's percentage of time devoted to Child Care in each time band, conditioned on age, day-of-week, family composition, father's occupation and women's working characteristics 2 Sample consists of non-retired/nonstudent fathers in couple with working mothers of children under 18 in the STUS (2002-2003) ${ }^{3}$ Each value represents correlations with the time devoted to Market Work activities by the wife, conditional on demographics ${ }^{4}$ Coefficients are multiplied by 100 . 
APPENDIX

Table A1 - Timing of Mothers $1,2,3,4$

\begin{tabular}{|c|c|c|c|c|c|c|c|c|c|c|c|c|}
\hline Timing of Mothers & 0-1 a.m. & 1-2 a.m. & 2-3 a.m. & 3-4 a.m. & 4-5 a.m. & 5-6 a.m. & 6-7 a.m. & 7-8 a.m. & 8-9 a.m. & 9-10 a.m. & 10-11 a.m. & 11-12 a.m. \\
\hline Market Work & $\begin{array}{c}0.612 \\
(0.829)\end{array}$ & $\begin{array}{c}0.862 \\
(0.834)\end{array}$ & $\begin{array}{c}0.196 \\
(0.686)\end{array}$ & $\begin{array}{l}-0.349 \\
(0.516)\end{array}$ & $\begin{array}{l}-0.532 \\
(0.483)\end{array}$ & $\begin{array}{l}-0.812 \\
(0.497)\end{array}$ & $\begin{array}{c}-1.691 \text { *** } \\
(0.625)\end{array}$ & $\begin{array}{c}-2.943^{* *} \\
(1.188)\end{array}$ & $\begin{array}{c}-11.929 * * * \\
(1.686)\end{array}$ & $\begin{array}{c}-9.940^{* * *} \\
(2.119)\end{array}$ & $\begin{array}{c}-4.498^{* *} \\
(2.038)\end{array}$ & $\begin{array}{l}-2.801 \\
(1.956)\end{array}$ \\
\hline Hhld Production & $\begin{array}{l}-0.247 \\
(0.422)\end{array}$ & $\begin{array}{l}-0.429 * \\
(0.225)\end{array}$ & $\begin{array}{l}-0.007 \\
(0.007)\end{array}$ & $\begin{array}{l}-0.034 \\
(0.030)\end{array}$ & $\begin{array}{l}0.077 \\
(0.081)\end{array}$ & $\begin{array}{l}-0.039 \\
(0.062)\end{array}$ & $\begin{array}{c}-0.552^{* *} \\
(0.250)\end{array}$ & $\begin{array}{l}1.946^{*} \\
(1.099)\end{array}$ & $\begin{array}{c}4.522^{* * *} \\
(1.313)\end{array}$ & $\begin{array}{c}5.472^{* * *} \\
(1.421)\end{array}$ & $\begin{array}{c}2.988^{* *} \\
(1.522)\end{array}$ & $\begin{array}{c}0.599 \\
(1.329)\end{array}$ \\
\hline Child care & $\begin{array}{c}0.293 \\
(0.434)\end{array}$ & $\begin{array}{c}0.279 \\
(0.357)\end{array}$ & $\begin{array}{l}-0.073 \\
(0.162)\end{array}$ & $\begin{array}{c}0.185 \\
(0.243)\end{array}$ & $\begin{array}{l}-0.109 \\
(0.165)\end{array}$ & $\begin{array}{l}-0.145 \\
(0.106)\end{array}$ & $\begin{array}{c}-0.400^{* * *} \\
(0.123)\end{array}$ & $\begin{array}{c}-1.287 * * * \\
(0.479)\end{array}$ & $\begin{array}{c}0.330 \\
(0.905)\end{array}$ & $\begin{array}{c}1.772^{* * *} \\
(0.623)\end{array}$ & $\begin{array}{l}1.113^{*} \\
(0.653)\end{array}$ & $\begin{array}{l}1.572^{*} \\
(0.802)\end{array}$ \\
\hline Aggregated Housework & $\begin{array}{c}0.049 \\
(0.649)\end{array}$ & $\begin{array}{l}-0.157 \\
(0.427)\end{array}$ & $\begin{array}{l}-0.148 \\
(0.159)\end{array}$ & $\begin{array}{c}0.121 \\
(0.251)\end{array}$ & $\begin{array}{l}-0.081 \\
(0.189)\end{array}$ & $\begin{array}{l}-0.220^{*} \\
(0.128)\end{array}$ & $\begin{array}{c}-1.001^{* * *} \\
(0.284)\end{array}$ & $\begin{array}{c}0.632 \\
(1.251)\end{array}$ & $\begin{array}{l}4.875^{* * * *} \\
(1.553)\end{array}$ & $\begin{array}{c}7.375^{* * *} \\
(1.561)\end{array}$ & $\begin{array}{c}4.260^{* * *} \\
(1.637)\end{array}$ & $\begin{array}{c}2.283 \\
(1.505)\end{array}$ \\
\hline N. Obs & 1,433 & 1,433 & 1,433 & 1,433 & 1,433 & 1,433 & 1,433 & 1,433 & 1,433 & 1,433 & 1,433 & 1,433 \\
\hline Market Work & $\begin{array}{l}-1.251 \\
(1.957)\end{array}$ & $\begin{array}{c}-4.694 * * \\
(2.033)\end{array}$ & $\begin{array}{c}-10.907 * * * \\
(1.829)\end{array}$ & $\begin{array}{l}-0.597 \\
(1.921)\end{array}$ & $\begin{array}{c}3.626 \\
(2.207)\end{array}$ & $\begin{array}{c}11.215^{* * *} \\
(2.099)\end{array}$ & $\begin{array}{c}14.720^{* * *} \\
(2.201)\end{array}$ & $\begin{array}{c}12.919 * * * \\
(2.230)\end{array}$ & $\begin{array}{c}5.889 * * * \\
(1.783)\end{array}$ & $\begin{array}{l}1.689 \\
(1.366)\end{array}$ & $\begin{array}{l}2.770^{* *} \\
(1.286)\end{array}$ & $\begin{array}{c}0.147 \\
(0.107)\end{array}$ \\
\hline Hhld Production & $\begin{array}{l}-0.031 \\
(1.285)\end{array}$ & $\begin{array}{l}2.311^{*} \\
(1.364)\end{array}$ & $\begin{array}{c}4.006^{* * *} \\
(1.312)\end{array}$ & $\begin{array}{l}1.257 \\
(1.553)\end{array}$ & $\begin{array}{l}-1.473 \\
(1.510)\end{array}$ & $\begin{array}{c}-3.165^{* *} \\
(1.428)\end{array}$ & $\begin{array}{c}-3.684^{* * *} \\
(1.263)\end{array}$ & $\begin{array}{c}-5.639 * * * \\
(1.386)\end{array}$ & $\begin{array}{l}-2.522 \\
(1.663)\end{array}$ & $\begin{array}{l}-0.450 \\
(1.541)\end{array}$ & $\begin{array}{l}-0.223 \\
(1.320)\end{array}$ & $\begin{array}{l}-0.016 \\
(0.097)\end{array}$ \\
\hline Child care & $\begin{array}{l}-0.315 \\
(0.442)\end{array}$ & $\begin{array}{c}1.904 * * \\
(0.918)\end{array}$ & $\begin{array}{c}0.905 \\
(0.612)\end{array}$ & $\begin{array}{c}0.568 \\
(0.605)\end{array}$ & $\begin{array}{l}-1.226^{*} \\
(0.708)\end{array}$ & $\begin{array}{c}-2.957 * * * \\
(0.854)\end{array}$ & $\begin{array}{l}-1.926^{*} \\
(1.036)\end{array}$ & $\begin{array}{l}-0.970 \\
(1.128)\end{array}$ & $\begin{array}{c}0.186 \\
(1.193)\end{array}$ & $\begin{array}{l}-0.037 \\
(0.994)\end{array}$ & $\begin{array}{c}0.485 \\
(0.701)\end{array}$ & $\begin{array}{l}-0.015 \\
(0.042)\end{array}$ \\
\hline Aggregated Housework & $\begin{array}{l}-0.252 \\
(1.373)\end{array}$ & $\begin{array}{c}4.290 * * * \\
(1.601)\end{array}$ & $\begin{array}{c}4.952^{* * *} \\
(1.435)\end{array}$ & $\begin{array}{c}1.962 \\
(1.641)\end{array}$ & $\begin{array}{l}-2.683 \\
(1.632)\end{array}$ & $\begin{array}{c}-6.502^{* * *} \\
(1.520)\end{array}$ & $\begin{array}{c}-6.090^{* * *} \\
(1.563)\end{array}$ & $\begin{array}{c}-7.087 * * * \\
(1.750)\end{array}$ & $\begin{array}{l}-2.803 \\
(1.918)\end{array}$ & $\begin{array}{l}-0.684 \\
(1.597)\end{array}$ & $\begin{array}{c}0.270 \\
(1.456)\end{array}$ & $\begin{array}{l}-0.032 \\
(0.105)\end{array}$ \\
\hline N. Obs & 1,433 & 1,433 & 1,433 & 1,433 & 1,433 & 1,433 & 1,433 & 1,433 & 1,433 & 1,433 & 1,433 & 1,433 \\
\hline
\end{tabular}

Notes: ${ }^{1}$ Robust standard errors in parenthesis ${ }^{2}$ Sample consists of non-retired/non-student partnered working mothers of children under 18 in the STUS (2002-2003) ${ }^{3}$ The time devoted to each activity is measured in minutes per day $4 *$ Significant at $10 \%$ level $* *$ Significant at $5 \%$ level $* * *$ Significant at $1 \%$ level.

Table A2 - Correlations between Child Care of Men and Market Work of Mothers 1,2,3,4

\begin{tabular}{|c|c|c|c|c|c|c|c|c|c|c|c|c|}
\hline Timing of Child Care for Men & $0-1$ a.m. & 1-2 a.m. & 2-3 a.m. & 3-4 a.m. & 4-5 a.m. & 5-6 a.m. & 6-7 a.m. & 7-8 a.m. & 8-9 a.m. & 9-10 a.m. & 10-11 a.m. & 11-12 a.m. \\
\hline Wife devotes time to Market Work in time band $(1,0)$ & $\begin{array}{c}0.039 \\
(0.028)\end{array}$ & $\begin{array}{c}-0.013^{*} \\
(0.007)\end{array}$ & $\begin{array}{c}-0.014 * \\
(0.008)\end{array}$ & $\begin{array}{c}-0.024 * * \\
(0.011)\end{array}$ & $\begin{array}{c}0.023 \\
(0.030)\end{array}$ & $\begin{array}{l}-0.006 \\
(0.004)\end{array}$ & $\begin{array}{c}0.005 \\
(0.012)\end{array}$ & $\begin{array}{c}0.049 * * \\
(0.021)\end{array}$ & $\begin{array}{c}0.073^{* * *} \\
(0.017)\end{array}$ & $\begin{array}{l}0.020^{*} \\
(0.011)\end{array}$ & $\begin{array}{c}0.006 \\
(0.011)\end{array}$ & $\begin{array}{l}-0.008 \\
(0.012)\end{array}$ \\
\hline Observations & 1,448 & 1,448 & 1,448 & 1,448 & 1,448 & 1,448 & 1,448 & 1,448 & 1,448 & 1,448 & 1,448 & 1,448 \\
\hline Timing of Child Care for Men & $12-1$ p.m. & 1-2p.m. & $2-3$ p.m. & 3-4 p.m. & 4-5 p.m. & 5-6 p.m. & 6-7 p.m. & $7-8$ p.m. & 8-9 p.m. & 9-10 p.m. & 10-11 p.m. & 11-12 p.m. \\
\hline Wife devotes time to Market Work in time band $(1,0)$ & $\begin{array}{c}0.009 \\
(0.010)\end{array}$ & $\begin{array}{c}0.017 \\
(0.012)\end{array}$ & $\begin{array}{c}0.031 * * * \\
(0.011)\end{array}$ & $\begin{array}{c}0.016 \\
(0.012)\end{array}$ & $\begin{array}{c}0.001 \\
(0.012)\end{array}$ & $\begin{array}{c}0.043^{* * *} \\
(0.015)\end{array}$ & $\begin{array}{c}0.032^{* *} \\
(0.015)\end{array}$ & $\begin{array}{c}0.037^{* *} \\
(0.019)\end{array}$ & $\begin{array}{c}0.018 \\
(0.023)\end{array}$ & $\begin{array}{c}0.008 \\
(0.030)\end{array}$ & $\begin{array}{c}0.022 \\
(0.033)\end{array}$ & $\begin{array}{l}-0.040 \\
(0.059)\end{array}$ \\
\hline Observations & 1,448 & 1,448 & 1,448 & 1,448 & 1,448 & 1,448 & 1,448 & 1,448 & 1,448 & 1,448 & 1,448 & 1,448 \\
\hline
\end{tabular}

Notes: 1 Robust standard errors in parenthesis ${ }^{2}$ consists of non-retired/non-student fathers in couple with working mothers of children under 18 in the STUS (2002-2003) ${ }^{3}$ Child Care is measured in percentage points (e.g., proportion of Child Care in each time band) $4 *$ Significant at $10 \%$ level $* *$ Significant at $5 \%$ level $* * *$ Significant at $1 \%$ level.

Editorial Office, Dept of Economics, Warwick University, Coventry CV4 7AL, UK 